\title{
Mesenchymal Metaplasia
}

National Cancer Institute

\section{Source}

National Cancer Institute. Mesenchymal Metaplasia. NCI Thesaurus. Code C54710.

A morphologic finding that refers to the transformation or replacement of a group of non-mesenchymal cells into osseous, cartilagenous, or lipomatous cells. 